\title{
Geochemical and Mineralogical Variation Of Hydrothermally Altered Rhyolite At Teerayuth Mine, Ban Laeng, Amphoe Muang, Lampang Province, Thailand
}

\author{
Keadsuda Donmuang ${ }^{*}$, Pongpor Asnachinda ${ }^{1}$, Phisit Limtrakun ${ }^{1}$, \\ Benjavan Rattanasatien ${ }^{1}$ and Wittaya Khandarosa ${ }^{1}$ \\ ${ }^{I}$ Department of Geological Sciences, Faculty of Sciences, Chiang Mai University, Chiang Mai, 50200, Thailand
}

\begin{abstract}
Different clay samples from Teerayuth Mine, Ban Laeng, Amphoe Muang, Lampang province were analyzed to obtain their mineralogical and chemical characteristics. Each sample was collected from different degree of alteration areas namely low, moderate and high as classified by their physical appearances at the mine faces. The samples were then determined for their geochemical and mineralogical composition. The results show that geochemistry and mineralogy of clays from Teerayuth Mine are varied from place to place. Results of the investigation clearly show the relationship between $\mathrm{SiO}_{2}$ content and the degrees of alteration. A representative sample of low alteration has higher $\mathrm{SiO}_{2}$ content than the high alteration sample. Additionally, illite was found in low alteration sample whereas kaolinite was found in high alteration sample. The alterations are closely related to fracture system, since fractures are commonly present in this area.
\end{abstract}

Keywords: hydrothermal alteration, kaolin, Lampang, mineralogy

\section{Introduction}

The northern part of Thailand is the important source of kaolin deposit (Figure 1). The largest kaolin deposit is in Lampang province. It is also the first kaolin deposit of Thailand that has been operated for ceramic production. Lampang province is approximately 100 kilometers to the south of Chiang Mai province. The kaolin in this area has been used in ceramic industry, the major industry of Lampang province of about 200 ceramic factories, for over 50 years. There are many kaolin deposits in Lampang area. Presently, there are three main deposits which are Khao Pang Kha deposit, Doi Mon Pan Kham deposit, and Ban Na Mai deposit. Department of Mineral Resources (2003)[1] assessed that kaolin reserves of Thailand were about 182.79 million tones. The important sources were Had Som Pan, Amphoe Muang, Ranong province, Khao Pang Kha and Huai Pan, Amphoe Jae Hom, Lampang province. There are approximately 68 million tones in Lampang. Most of kaolin was used for making tableware in ceramic industry. Aranyabhaga (1997)[2] stated that Lampang china stone was first discovered about 50 years ago at Khao Pang Kha, Amphoe Jae Hom, Lampang province long after its household utilization as a grinding stone for knives - sharpening. Since then it has been used mainly as ceramic raw material for about fifty years.

Lampang kaolin deposit is primary kaolin by the alteration of rhyolite and rhyolitic tuff (Jaitabutr, 2009)[3]. According to Poom-im (1981)[4] suggested that Lampang clay should be called 'illitic clay' instead of kaolin since kaolin is called for clay which is composed mainly of Kaolinite. Department of Mineral Resources (1993)[5] found that some of Lampang china stone were micro - pegmatite or aplite. It could be used as a source of feldspar and quartz. In addition, Lampang china stone from Khao Pang Kha which was suitable for ceramic making was greisen or quartz - sericite schist (Department of Mineral Resources, 1993).

\section{Geologic Setting}

Teerayuth Mine is located in Tambon Ban Laeng Amphoe Muang, Lampang province in the northern part of Thailand. The reference topographic map of the scale 1:250,000 is NE47-7 (Changwat Lampang), and of the scale 1:50,000 series L7017 is 4945 IV (Changwat Lampang). The area covers approximately one square kilometer and lies approximately between latitude of $18^{\circ} 27^{\prime} \mathrm{N}$ to $18^{\circ} 29^{\prime} \mathrm{N}$ and longitude $99^{\circ} 34^{\prime} \mathrm{E}$ to $99^{\circ} 37^{\prime}$ E (Figure 2). The regional geology of the area is composed mainly of igneous rocks including Permo-Triassic volcanic rocks. They comprises of rhyolite, andesite, tuff and agglomerate (Piyasin, 1971)[6]. 


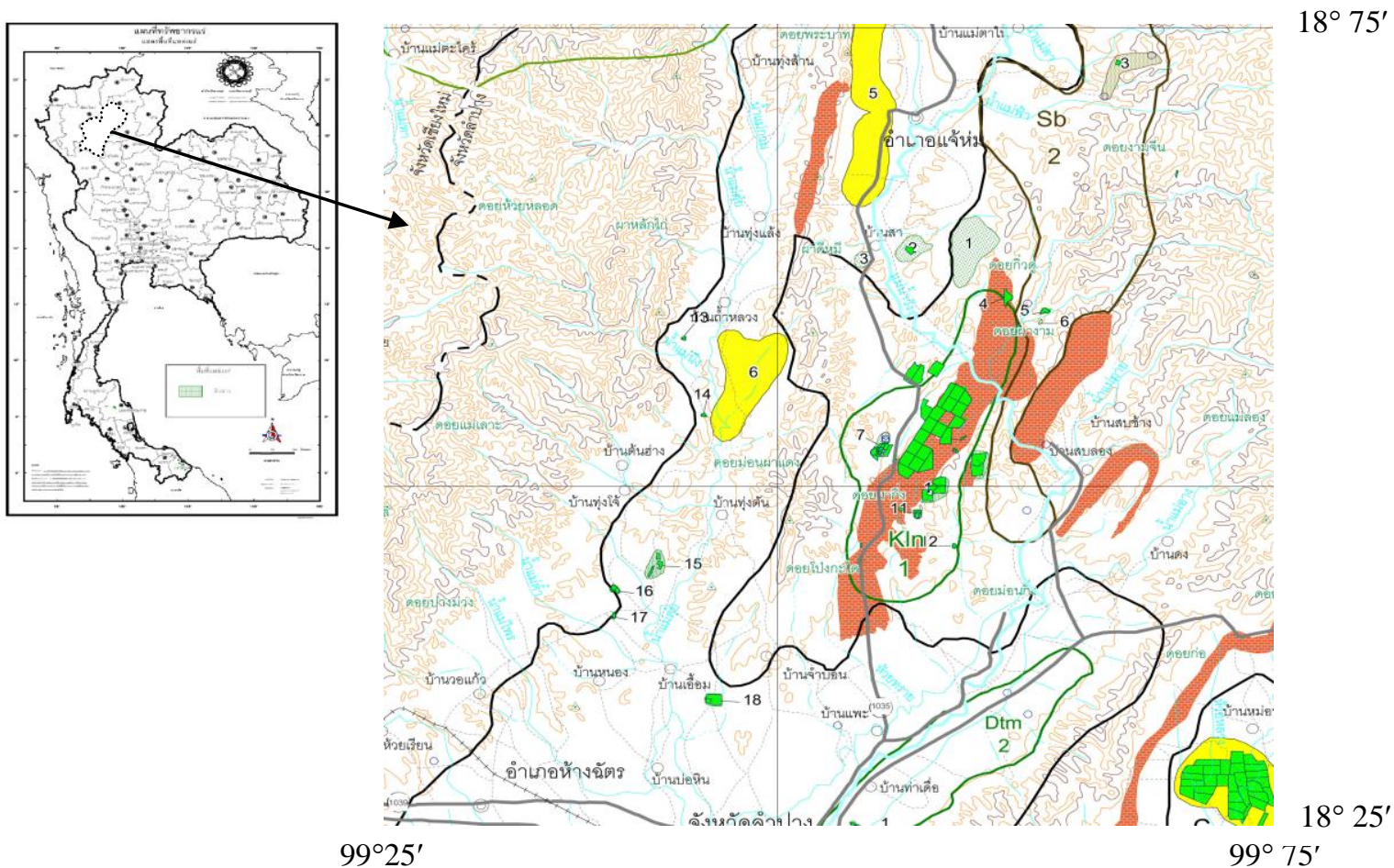

Figure 1 Kaolin deposits in Thailand ( $\square$ kaolin deposit) (modified after Department of Mineral Resources, 2003) Scale 1:250,000

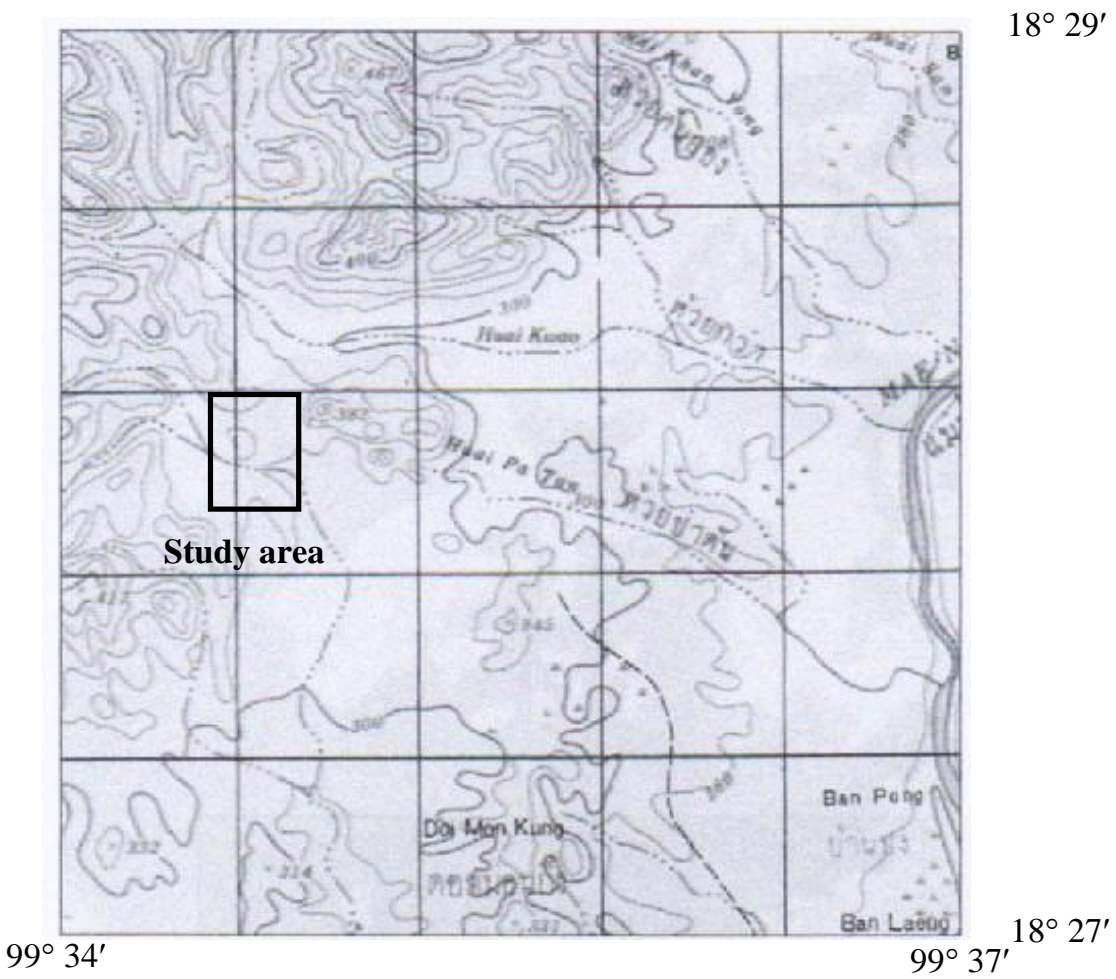

Figure 2 Topographic map of the study area, Teerayuth Mine, Muang, Lampang, N Thailand (modified after Piyasin, 1971). 


\section{Materials And Methods}

The clay samples were collected from three representative zones based on degrees of alteration namely low, moderate and high alteration. All samples were analyzed for mineralogical and chemical composition. Sample preparation procedure was based on the strength of the samples. Samples with no strength or low strength were dried at $110^{\circ} \mathrm{C}$ in an electric oven for 24 hours. Then, the samples were taken out from the oven and cooled down to room temperature. Finally, the samples were grinded to pass through 200 mesh testing sieve and analyzed for chemical composition and mineral composition. Fusion method was used for sample preparation for chemical analysis because this method has been known to be the best method for the analysis by minimizing grain size effect. The testpieces by fusion method are generally called 'glass bead'. Glass bead is prepared by weighing $1 \mathrm{~g}$. of 200 mesh sample and dry at $110^{\circ} \mathrm{C}$ for 24 hours. Cool down the dried sample in a desiccator to avoid moisture absorption and record the dried weight $\left(\mathrm{W}_{1}\right)$. Fire the dried sample in an electric kiln at about $1000{ }^{\circ} \mathrm{C}$. After firing and cooling, weigh the fired sample and record the after firing weight $\left(\mathrm{W}_{2}\right)$, the dried and fired weigh are used for calculating the value of loss on ignition (LOI). Glass bead was prepared by mixing $0.5 \mathrm{~g}$. fired powder with $5 \mathrm{~g}$. di - lithium tetraborate $\left(\mathrm{Li}_{2} \mathrm{~B}_{4} \mathrm{O}_{7}\right)$ in a platinum crucible and then fused by fusion machine. Major oxides consisted of $\mathrm{SiO}_{2}, \mathrm{TiO}_{2}, \mathrm{Al}_{2} \mathrm{O}_{3}, \mathrm{Fe}_{2} \mathrm{O}_{3}, \mathrm{MnO}, \mathrm{MgO}, \mathrm{CaO}, \mathrm{K}_{2} \mathrm{O}$ and $\mathrm{Na}_{2} \mathrm{O}$ was done by a Phillips - MagixPRO wavelength dispersive X - Ray Fluorescence Spectrometer.

Mineralogical analysis was done by drying bulk samples at $110^{\circ} \mathrm{C}$ for 24 hours in an electric oven and cooled down before grinding into 200 mesh size or 44 micron. The clay fraction was separated from the bulk sample by sedimentation and mounted as an oriented aggregate for clay-mineral identification. The treatments included air drying, glycolation with ethylene glycol, and heating to $550{ }^{\circ} \mathrm{C}$ were used for this analysis (Poppe et al., 2012)[7].

\subsection{GEOCHEMICAL ANALYSIS}

\section{Results And Discussion}

$\mathrm{X}$-Ray Fluorescence spectrometer was used for geochemical analysis. Chemical composition in the forms of $\mathrm{SiO}_{2}, \mathrm{Al}_{2} \mathrm{O}_{3}, \mathrm{~K}_{2} \mathrm{O}, \mathrm{Na}_{2} \mathrm{O}, \mathrm{CaO}, \mathrm{MgO}, \mathrm{Fe}_{2} \mathrm{O}_{3}, \mathrm{TiO}_{2}, \mathrm{MnO}_{2}$ and LOI (Loss on Ignition) are analyzed. It clearly shows the relationship between $\mathrm{SiO}_{2}$ content and the degrees of alteration. The samples of low alteration show higher $\mathrm{SiO}_{2}$ content than high alteration samples (Table 1).

Table 1 Chemical compositions of samples from fresh/no, low, moderate and high degree of alteration

\begin{tabular}{|c|c|c|c|c|c|c|c|c|c|c|}
\hline Degree of Alteration & $\mathrm{SiO}_{2}(\%)$ & $\begin{array}{c}\mathrm{Al}_{2} \mathrm{O}_{3} \\
(\%)\end{array}$ & $\begin{array}{c}\mathrm{K}_{2} \mathrm{O} \\
(\%) \\
\end{array}$ & $\begin{array}{c}\mathrm{Na}_{2} \mathrm{O} \\
(\%)\end{array}$ & $\begin{array}{c}\mathrm{CaO} \\
(\%)\end{array}$ & $\begin{array}{c}\text { MgO } \\
(\%) \\
\end{array}$ & $\begin{array}{c}\mathrm{Fe}_{2} \mathrm{O}_{3} \\
(\%) \\
\end{array}$ & $\begin{array}{l}\mathrm{TiO}_{2} \\
(\%)\end{array}$ & $\begin{array}{c}\mathrm{MnO}_{2} \\
(\%)\end{array}$ & $\begin{array}{c}\text { LOI } \\
(\%) \\
\end{array}$ \\
\hline $\begin{array}{c}\text { Fresh/No } \\
\text { min. } \\
\max .\end{array}$ & $\begin{array}{l}56.601 \\
72.624\end{array}$ & $\begin{array}{l}16.757 \\
21.043\end{array}$ & $\begin{array}{l}4.966 \\
6.987\end{array}$ & $\begin{array}{l}0.173 \\
1.546\end{array}$ & $\begin{array}{l}0.267 \\
0.495\end{array}$ & $\begin{array}{l}0.119 \\
0.444\end{array}$ & $\begin{array}{l}0.555 \\
9.117\end{array}$ & $\begin{array}{l}0.059 \\
0.192\end{array}$ & $\begin{array}{l}0.012 \\
1.359\end{array}$ & $\begin{array}{l}1.010 \\
6.730\end{array}$ \\
\hline $\begin{array}{l}\text { Low } \\
\text { min. } \\
\max .\end{array}$ & $\begin{array}{l}69.953 \\
75.923 \\
\end{array}$ & $\begin{array}{l}14.493 \\
18.852\end{array}$ & $\begin{array}{l}5.395 \\
7.189\end{array}$ & $\begin{array}{l}0.098 \\
1.150\end{array}$ & $\begin{array}{l}0.137 \\
0.400 \\
\end{array}$ & $\begin{array}{l}0.149 \\
0.259\end{array}$ & $\begin{array}{l}0.363 \\
0.636\end{array}$ & $\begin{array}{l}0.042 \\
0.072\end{array}$ & $\begin{array}{l}0.006 \\
0.058\end{array}$ & $\begin{array}{l}2.170 \\
3.400 \\
\end{array}$ \\
\hline $\begin{array}{c}\text { Moderate } \\
\text { min. } \\
\max .\end{array}$ & $\begin{array}{l}66.990 \\
74.469\end{array}$ & $\begin{array}{l}16.795 \\
20.464\end{array}$ & $\begin{array}{l}4.439 \\
7.649\end{array}$ & $\begin{array}{l}0.010 \\
0.186\end{array}$ & $\begin{array}{l}0.063 \\
0.260\end{array}$ & $\begin{array}{l}0.184 \\
0.628\end{array}$ & $\begin{array}{l}0.599 \\
1.639\end{array}$ & $\begin{array}{l}0.049 \\
0.454\end{array}$ & $\begin{array}{l}0.000 \\
0.039\end{array}$ & $\begin{array}{l}2.650 \\
3.630\end{array}$ \\
\hline $\begin{array}{c}\text { High } \\
\text { min. } \\
\max .\end{array}$ & $\begin{array}{l}61.395 \\
67.852\end{array}$ & $\begin{array}{l}18.410 \\
26.186\end{array}$ & $\begin{array}{l}3.983 \\
4.321\end{array}$ & $\begin{array}{l}0.024 \\
0.131\end{array}$ & $\begin{array}{l}0.048 \\
3.248\end{array}$ & $\begin{array}{l}0.277 \\
0.372\end{array}$ & $\begin{array}{l}0.575 \\
0.861\end{array}$ & $\begin{array}{l}0.033 \\
0.075\end{array}$ & $\begin{array}{l}0.009 \\
0.010\end{array}$ & $\begin{array}{l}5.115 \\
6.930\end{array}$ \\
\hline
\end{tabular}

\subsection{MINERALOGICAL ANALYSIS}

The collected samples were analyzed by X-Ray Diffractometer (XRD) model X-pert, Philips. The interpretation of XRD patterns led to the identification of the following mineral phases: muscovite/illite, kaolinite and quartz with minor amount of feldspar. The XRD patterns show that muscovite/illite is rich in low alteration samples whereas kaolinite was found in high alteration samples (Table 2, Figure 3 and Figure 4).

Table 2 Mineral composition of samples from fresh/no, low, moderate and high degree of alteration

\begin{tabular}{|c|c|c|c|c|c|c|}
\hline Degree of Alteration & $\begin{array}{c}\text { quartz } \\
(\%)\end{array}$ & $\begin{array}{c}\text { albite } \\
(\%)\end{array}$ & $\begin{array}{c}\text { potassium feldspar } \\
(\%)\end{array}$ & $\begin{array}{c}\text { kaolinite } \\
(\%)\end{array}$ & $\begin{array}{l}\text { illite } \\
(\%)\end{array}$ & $\begin{array}{c}\text { montmorillonite } \\
(\%)\end{array}$ \\
\hline $\begin{array}{c}\text { Fresh/No } \\
\text { min. } \\
\max .\end{array}$ & $\begin{array}{l}41.39 \\
55.40\end{array}$ & $\begin{array}{l}31.45 \\
38.87\end{array}$ & $\begin{array}{l}0.00 \\
8.14\end{array}$ & $\begin{array}{l}2.32 \\
2.44\end{array}$ & $\begin{array}{l}2.10 \\
8.43\end{array}$ & $\begin{array}{l}6.30 \\
9.82\end{array}$ \\
\hline $\begin{array}{l}\text { Low } \\
\text { min. } \\
\text { max. }\end{array}$ & $\begin{array}{r}55.91 \\
91.94 \\
\end{array}$ & $\begin{array}{l}0.00 \\
0.00 \\
\end{array}$ & $\begin{array}{r}1.69 \\
35.18 \\
\end{array}$ & $\begin{array}{r}1.2 \\
2.15 \\
\end{array}$ & $\begin{array}{c}3.71 \\
11.86 \\
\end{array}$ & $\begin{array}{l}1.65 \\
2.38 \\
\end{array}$ \\
\hline $\begin{array}{l}\text { Moderate } \\
\text { min. }\end{array}$ & 82.22 & 0.00 & 0.00 & 3.37 & 3.55 & 0.65 \\
\hline
\end{tabular}


Geochemical and Mineralogical Variation Of Hydrothermally Altered Rhyolite At Theerayut...

\begin{tabular}{|c|c|c|c|c|c|c|}
\cline { 2 - 7 } max. & 96.44 & 0.00 & 0.96 & 0.62 & 12.44 \\
\hline High & 78.04 & 0.00 & 0.00 & 2.97 & 3.2 & \\
min. & 89.90 & 0.00 & 0.00 & 12.28 & 9.68 & 0.00 \\
max. & & & & \\
\hline
\end{tabular}

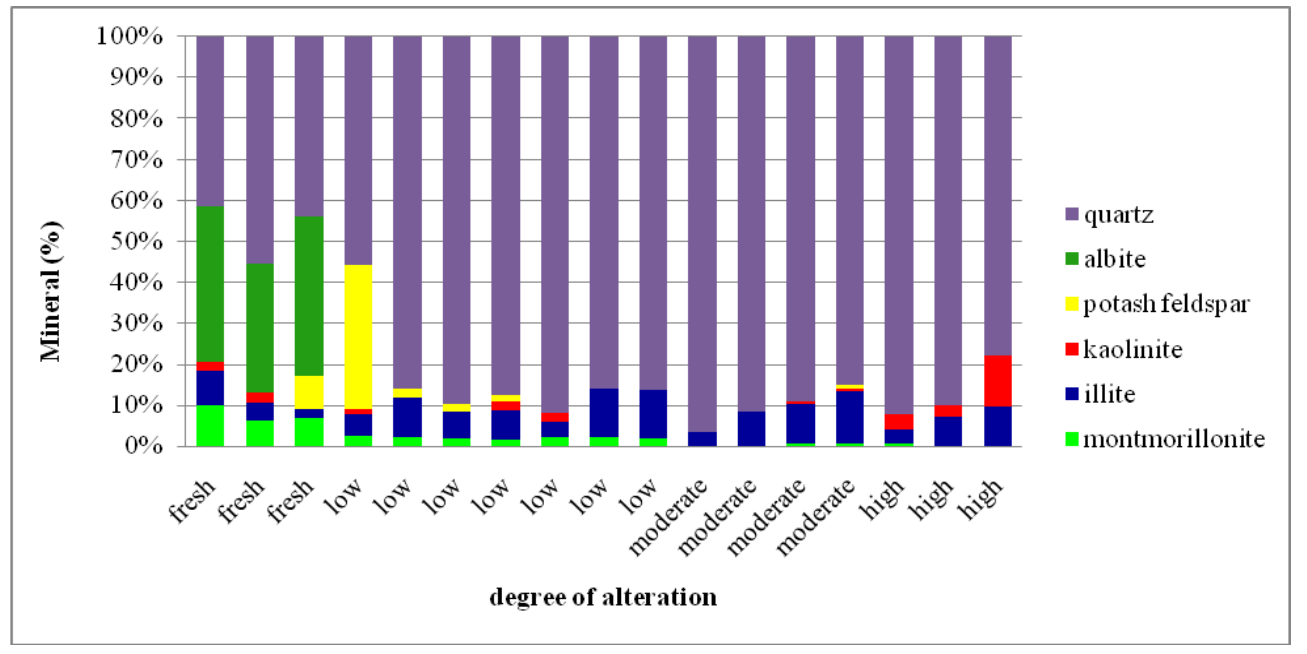

Figure 3 The comparison of mineral content in samples from different degree of alteration. The fresh samples show the highest content of albite, whereas samples of high degree of alteration contain considerably content of kaolinite.

\subsection{GEOCHEMICAL AND MINERALOGICAL VARIATION OF HYDROTHERMALLY ALTERED CLAYS AT TEERAYUTH MINE}

The variations of chemical composition and mineralogy with increasing degree of alteration reflect the nature of specific alteration processes. The relatively mobility of elements is controlled not only by primary factors such as the mineralogy and texture of the parent rock, but also by secondary processes such as dissolution of primary minerals, formation of secondary phases, redox processes, and ion exchange (Nesbitt $e t$ al., 1980[8]; Chesworth et al., 1981[9]; Gascoyne and Cramer 1987[10]; Middelburg et al., 1988[11]). In a thermodynamic sense, systems of chemical weathering and hydrothermal alteration are invariably open and irreversible (Cramer and Nesbitt, 1983[12]; Fritz and Mohr, 1984[13]). Aranyabhaga (1997) founded that Lampang china stone was composed of kaolinite, sericite, feldspar (albite), montmorillonite and quartz. According to this study, it is found that minerals consist in the clay samples are illite, kaolinite, montmorillonite, albite, and quartz. Chemical composition in the forms of $\mathrm{SiO}_{2}, \mathrm{Al}_{2} \mathrm{O}_{3}, \mathrm{Fe}_{2} \mathrm{O}_{3}, \mathrm{TiO}_{2}, \mathrm{MnO}_{2}, \mathrm{CaO}, \mathrm{MgO}, \mathrm{K}_{2} \mathrm{O}$, $\mathrm{Na}_{2} \mathrm{O}$ and LOI (Loss on Ignition) are analyzed. $\mathrm{SiO}_{2}, \mathrm{Al}_{2} \mathrm{O}_{3}$ slightly vary within the samples. $\mathrm{Fe}_{2} \mathrm{O}_{3}, \mathrm{TiO}_{2}$, $\mathrm{MnO}_{2}, \mathrm{CaO}, \mathrm{MgO}, \mathrm{K}_{2} \mathrm{O}, \mathrm{Na}_{2} \mathrm{O}$ and $\mathrm{LOI}$ are moderately different and can be divided into two groups. Obviously, the difference in $\mathrm{Na}_{2} \mathrm{O}$ content and in form of albite and montmorillonite shows a distinct characteristic of the clay samples of this mine. 


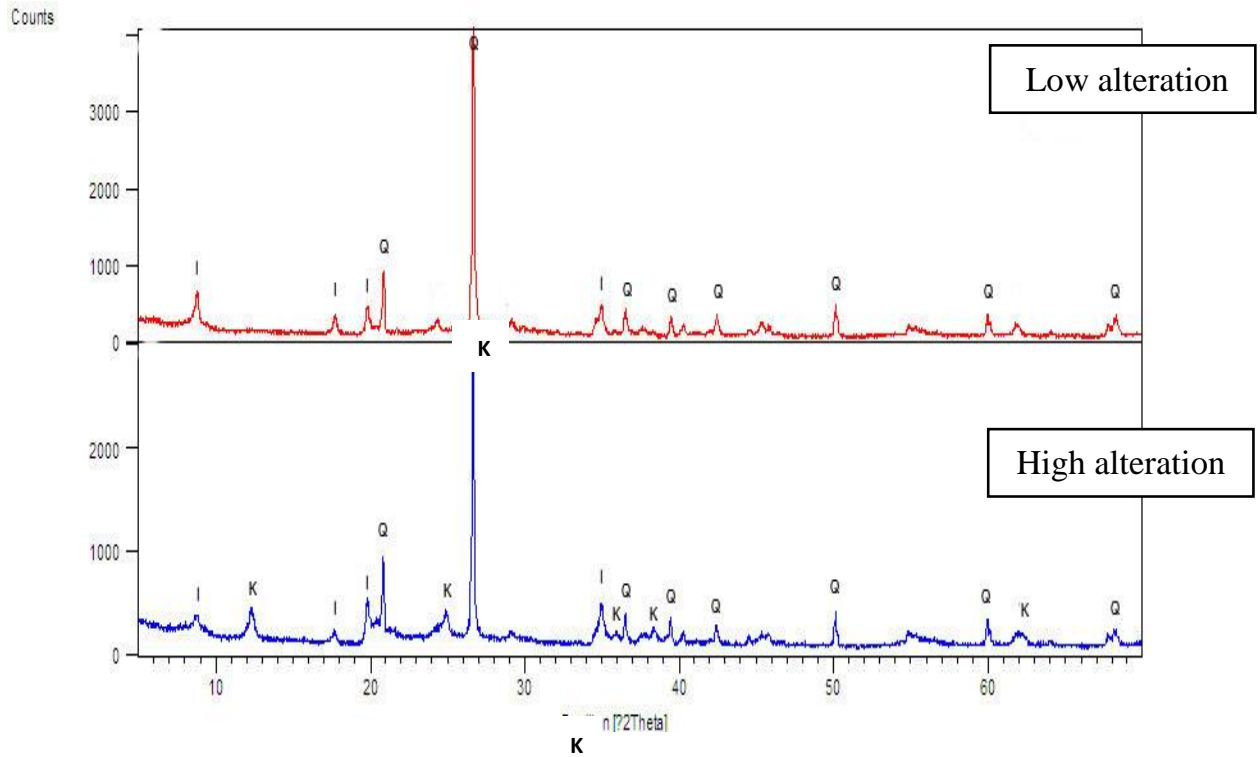

Figure 4 The comparison of XRD patterns of the samples from low and high alteration zones, kaolinite peaks are clearly shown in high alteration sample $(\mathrm{I}=$ illite, $\mathrm{K}=$ kaolinite, $\mathrm{Q}=$ quartz $)$

Teerayuth Mine covers the area of two main rhyolite pockets with a major fault and numbers of fractures. Porphyritic rhyolite was found in the northeastern of the mine with no mining operation. The main rhyolite pocket was found in the north - western of the mine and the smaller one was on the south - western. There was a sharp fault trending NW-SE of red sedimentary rock with limestone breccias overlaid the first rhyolite pocket. The area contains clay-rich zones and also partly altered to relatively fresh rhyolite. Cross sections showing schematic representation of hydrothermal alteration zone of this study area are shown in Figure 5. The alteration zones occur along the line of faulting and fractures. High alteration zone was found in the zone occupied by minor fault and fractures. It ranges from less than one meter to ten meters wide and probably one hundred meters long. After mineral evaluation by X - Ray Diffractometer of all samples were obtained, it was possible to group together samples that have similar mineralogical composition. The groups classified based on four minerals present which are albite, montmorillonite, illite, and kaolinite. The zone begins from fresh rhyolite as a vent. The raw materials were relatively fresh and rich in quartz and albite with small amount of muscovite or illite (Figure 6). Next to the rhyolite vent was the zone of raw materials consisted of quartz, small amount of montmorillonite and illite. This zone represents low alteration zone. The second zone represents moderate degree of alteration showing quartz, illite and small amount of kaolinite. The last zone further from the vent was abundant in quartz, greater amount of kaolinite and small amount of illite. This zone represents high alteration zone. Obviously, the zone of high degree of alteration is intense of fractures. XRD pattern of sample from high alteration zone with completely altered clearly shows high kaolinite peak with small amount of illite (Figure 7). The most intense alteration appeared to be in the south - western part of the mine with progressively less alteration area towards the north - eastern as suggested by the mineral distribution in the deposit. 


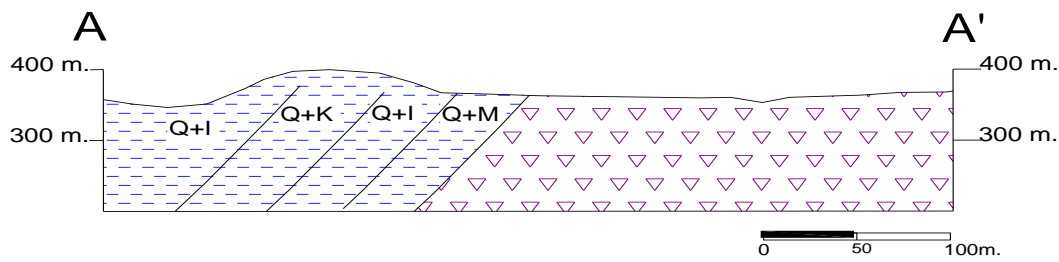

B $\quad B^{\prime}$
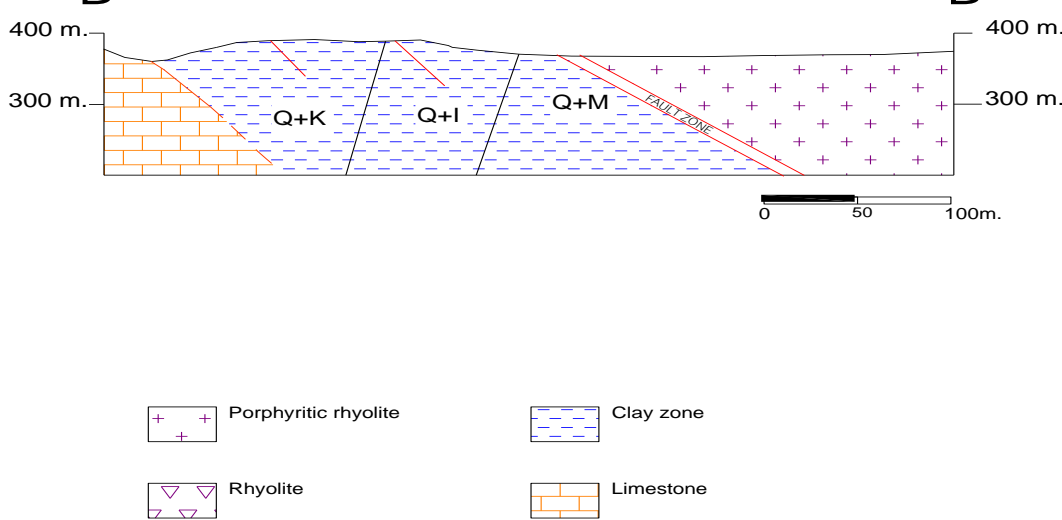

Figure 5 Cross section showing the schematic representation of structure and hydrothermal alteration zone of Teerayuth Mine.

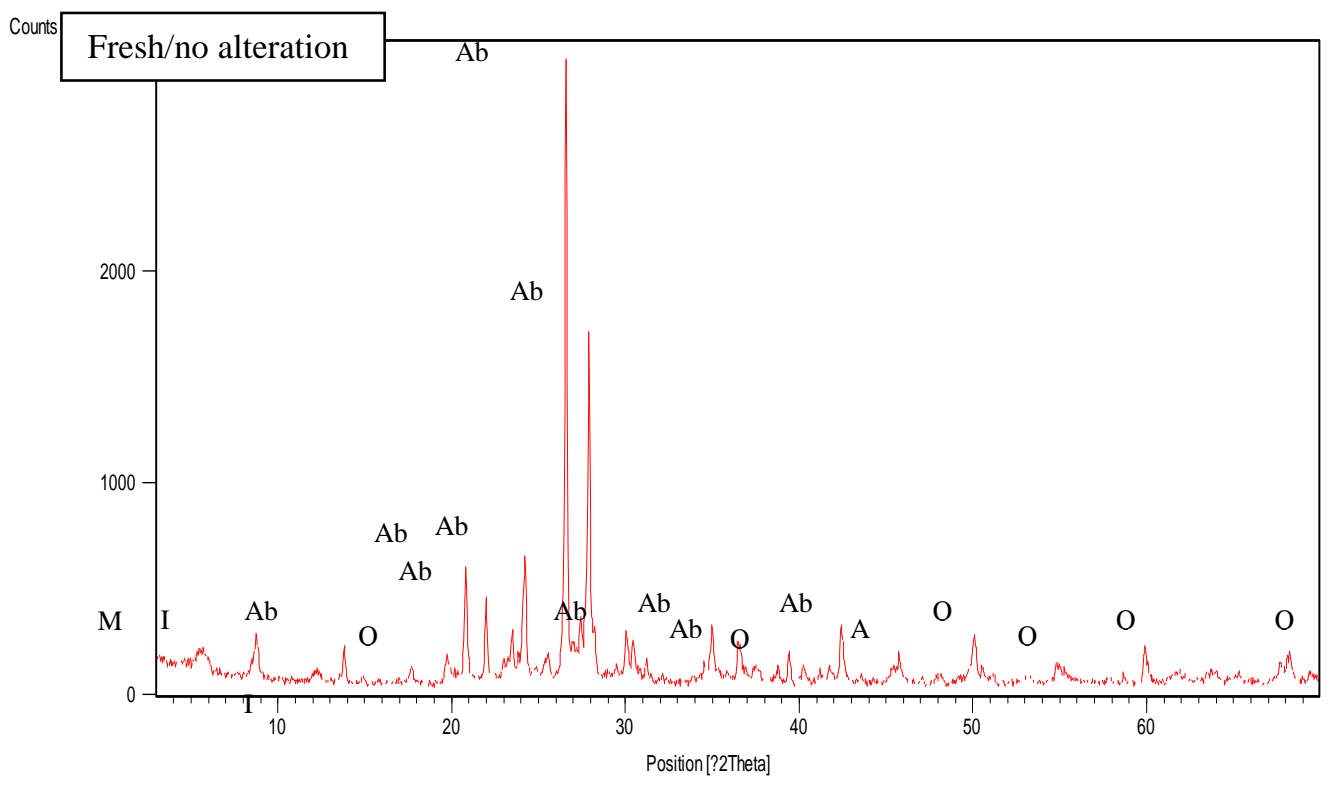

Figure 6 XRD pattern of fresh sample which is massive and relatively fresh rock clearly shows high content of quartz $(\mathrm{Q})$ and albite $(\mathrm{Ab})$, with small amount of illite and montmorillonite $(\mathrm{M})$. 


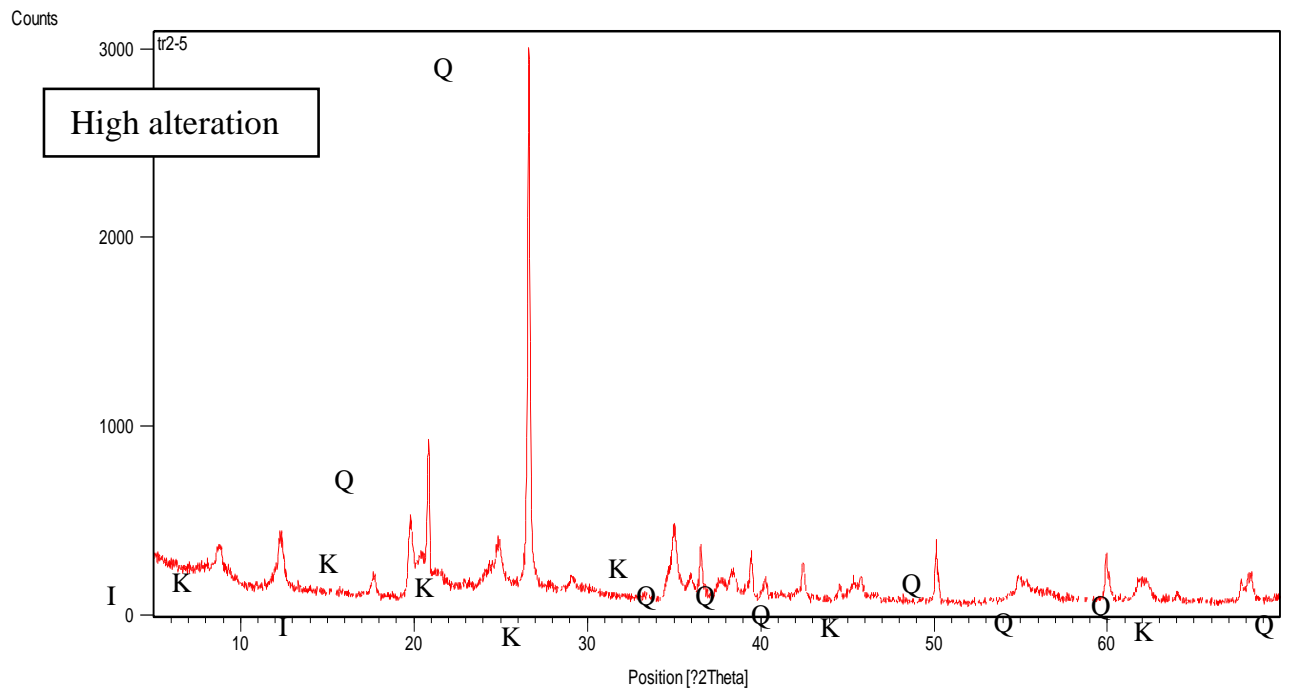

Figure 7 XRD pattern of high alteration sample represents quartz - kaolinite - illite zone with sharp peak of kaolinite ( $\mathrm{I}=$ illite, $\mathrm{K}=$ kaolinite, $\mathrm{Q}=$ quartz).

Hydrothermal fluids circulate in veins and fractures are mainly the cause of mineral reaction. Mineral assemblages change with the distance to the vein. Each zone is characterized by a dominating mineral whose proportions vary with distance. The width of the zone is dependent on the system temperature, among other factors (Meunier, 2005)[14]. Lovering, 1950 [15] proposed the zonal disposition of alteration most common in granites and related rocks as illustrated in Figure 8. There were classified into four zones. The first zone close to the vein was the sericitized zone in which the country rock is transformed into sericite. The second zone was argillic zone which includes clay rich in alumina such as kaolinite and dickite, associated locally with rutile, leucoxene and alunite. The third zone was montmorillonite - beidellite which the intensity of alteration decreases.

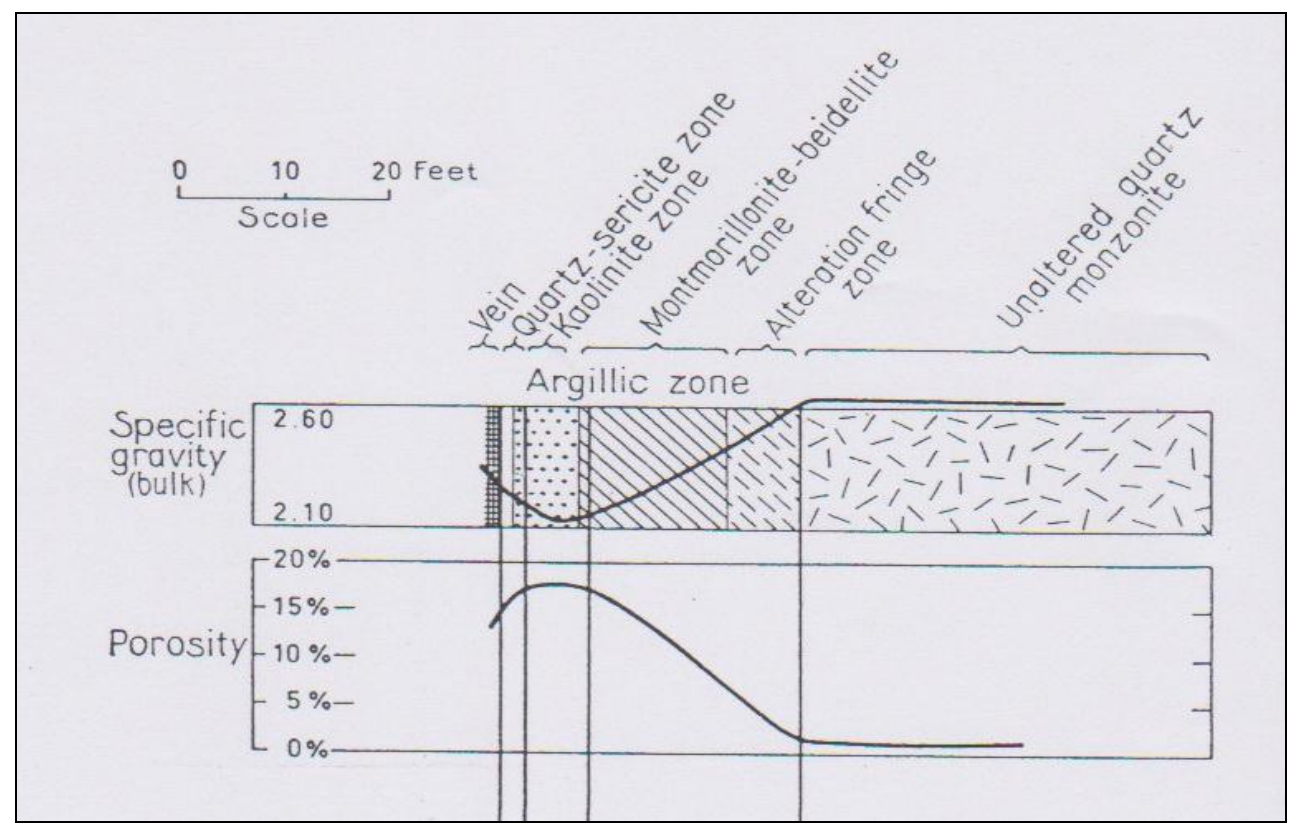

Figure 8 Hydrothermal alteration zone in quartz monzonites, Boulder County Tungsten district (after Lovering, 1950). 


\section{Conclusion}

In conclusion, geochemistry and mineralogy of clays at Teerayuth Mine vary within the area. The samples show the difference in physical appearances such as hardness and color that reflects the rate of alteration. According to the chemical analysis, the samples of low alteration have higher $\mathrm{SiO}_{2}$ content than the high alteration samples. Mineralogically, illite was found in low alteration sample whereas kaolinite was found in high alteration sample. These zones reflect progressive hydrothermal alteration process. The breakdown of feldspar and mica occurred at early stage of alteration, and abundant illite formed as alteration intensity increased. There are also fractures present in the area that leads to the movement of hydrothermal water to promote hydrothermal alteration of the parent rock. The mine consists of fresh rock to strongly altered rock. Since, illite, an index mineral of hydrothermal alteration, is found in this area. It is supported the idea of the genesis of Lampang kaolin in this deposit is hydrothermal alteration classified as phyllic alteration type according to main phase of illite, kaolinite and quartz.

\section{Acknowledgements}

The authors would like to acknowledge the Department of Geological Sciences, the Faculty of Sciences, Chiang Mai University for providing all facilities and materials to do this research work. We would like to thank The Graduated School, Chiang Mai University for providing a research grant. We also would like to thank Teerayuth Mine for his contribution of mine visiting and several useful data.

\section{References}

[1]. Department of Mineral Resources. 2003. Kaolin deposits in Thailand.

[2]. Aranyabhaga, Somboon, 1997. The Lampang China Stone, International conference on Materials, Technology: Recent Development and Future Potential, 9-10 January 1997, at The Empress Hotel, Chiangmai, Thailand.

[3]. Adul Jaitabutr. (2009) Kaolin and Ballclays of Thailand, Department of Mineral Resources.

[4]. Poom-Im, Somchai (1981) Comparison of Genesis and Clay-forming Minerals of Kaolin in North Thailand, Faculty of Sciences, Chiang Mai University.

[5]. Department of Mineral Resources. (1993) The Properties of Chinastone of Lampang.

[6]. Piyasin, S. 1971. Geological map of Changwat Lampang, scale 1:250,000, sheet NE 47-7. Geol. Surv. Div., DMR., Bangkok, Thailand.

[7]. Department of Primary Industries and Mines. (2011) Mineral Statistics of Thailand 2006-2010.

[8]. Nesbitt, H. W., Markovics, G. and Price, R. C. 1980. Chemical processes affecting alkalis and alkaline earths during continental weathering. Geochim. Cosmochim. Acta, 44, 1659-1666.

[9]. Chesworth, W., Dejou, J. and Larroque, P. 1981. The weathering of basalts and relative mobilities of the major elements at Belbex, France. Geochim. Cosmochim. Acta 45, 1235-1243.

[10]. Gascoyne, M. and Cramer, J. 1987. History of actinide and minor element mobility in an Archean batholith in Manitoba, Canada. Applied Geochem. 2, 37-53.

[11]. Middelburg, J. J., Van der Weijden, C. H. and Woittiez, J. R. W. 1988. Chemical processes affecting the mobility of major, minor and trace elements during weathering of granitic rocks. Chem. Geol. $\mathbf{6 8}$, 253-273.

[12]. Cramer, J. J. and Nesbitt, H. W. 1983. Mass-balance relations and trace element mobility during continental weathering of various igneous rocks. Symp. On Petrology of Weathering and Soils, Sci. Geol., Mem. 73, 63-73.

[13]. Fritz, S.J. and Mohr, D. W. 1984. Chemical alteration in the micro weathering environment within a spherolidally-weathered anorthite boulder. Geochim. Cosmochim. Acta 48, 2527-2535.

[14]. Meunier, A. 2005. Clays. Heidelberg, German: Springer-Vertag, 472 pp.

[15]. Lovering, T. S. 1950. The geochemistry of argillic and related types of rock alteration: Colorado School Mines Quart., v. 65, pp. 231-260. 